\title{
Efektivitas Vitamin E dan Deksametason pada Otak Tikus Putih
}

\author{
(THE EFFECT OF VITAMIN E AND DEXAMETASONE ON THE WHITE RATS BRAIN) \\ Afrizal Choirul Umam ${ }^{1}$, I Ketut Berata ${ }^{2}$, Samsuri $^{3}$, I Wayan Sudira ${ }^{3}$, \\ Luh Made Sudimartini ${ }^{3}$, I Made Merdana ${ }^{3 *}$ \\ ${ }^{1}$ Praktisi Dokter Hewan di Lumajang, ${ }^{2}$ Laboratorium Patologi Veteriner, ${ }^{3}$ Laboratorium \\ Famakologi dan Farmasi Veteriner Fakultas Kedokteran Hewan Universitas Udayana \\ Jalan PB. Sudirman Denpasar, Bali Telp. 0361-223791 Faks (0361) 223791 \\ *Email: imade_merdana@unud.ac.id
}

\begin{abstract}
ABSTRAK
Pemberian deksametason dalam jangka waktu yang lama dan dengan dosis besar dapat menimbulkan gangguan pada otak. Untuk mencegah gangguan terhadap otak, maka diperlukan antioksidan diantaranya yaitu vitamin E. Penelitian ini bertujuan untuk membuktikan bahwa pemberian deksametason menimbulkan gangguan pada otak tikus putih dan mengetahui efek pemberian suplementasi vitamin $\mathrm{E}$ dalam mencegah efek samping deksametason pada otak tikus putih. Penelitian ini menggunakan 25 ekor tikus putih jantan, dibagi dalam 5 kelompok perlakuan, yaitu kontrol negatif tanpa diberi perlakuan, kontrol positif diberikan deksametason dosis 0,13 $\mathrm{mg} / \mathrm{kgbb}$, dan kelompok perlakuan secara berurutan yang diberikan deksametason $0,13 \mathrm{mg} / \mathrm{kgbb}$ dan vitamin E $100 \mathrm{mg} / \mathrm{kgbb}$, deksametason $0,13 \mathrm{mg} / \mathrm{kgbb}$ dan vitamin E $150 \mathrm{mg} / \mathrm{kgbb}$, diberikan deksametason $0,13 \mathrm{mg} / \mathrm{kgbb}$ dan vitamin E $200 \mathrm{mg} / \mathrm{kgbb}$. Perlakuan diberikan selama 14 hari, kemudian hewan coba dinekropsi. Jaringan otak diambil dan diproses untuk pembuatan preparat histopatologi dengan teknik pewarnaan hematocilin-eosin. Variabel yang diperiksa meliputi adanya lesi edema perivaskuler dan kongesti. Hasil penelitian diperoleh adanya perbedaan yang nyata antara kontrol negatif dengan kontrol positif. Rerata skor perbaikan dari kerusakan otak tidak berbeda nyata antara perlakuan vitamin E dosis $100 \mathrm{mg} / \mathrm{kgbb}, 150 \mathrm{mg} / \mathrm{kgbb}$ dan $200 \mathrm{mg} / \mathrm{kgbb}$. Kelompok perlakuan vitamin E $100 \mathrm{mg} / \mathrm{kgbb}$ menunjukkan mendekati rerata skor kelompok control negatif. Simpulan dari penelitian ini adalah pemberian deksametason menyebabkan perubahan histopatologi otak tikus putih. Pemberian suplementasi vitamin E sampai dosis $200 \mathrm{mg} / \mathrm{kg}$ tidak mampu mengurangi efek deksametason pada otak.
\end{abstract}

Kata kunci: deksametason; otak; kerusakan otak; vitamin E.

\begin{abstract}
Provision of dexamethasone for the long term and large doses may cause disturbances in the brain. To prevent disruption to the brain, it needs antioxidant such as vitamin E. The aims of this study is to prove the administration of dexamethasone cause interference on white rat brain and determine the effects of vitamin E supplementation in preventing the side effects of dexamethasone in the brains of rats. This study used 25 male rats were divided into 5 groups, namely negative control was only given food and drink, positive control is given dexamethasone at a dose of $0.13 \mathrm{mg} / \mathrm{kg} \mathrm{bw}$, $\mathrm{P} 1$ given dexamethasone $0.13 \mathrm{mg} / \mathrm{kg}$ of body weight and vitamin $\mathrm{E}$ at a dose of $100 \mathrm{mg} / \mathrm{kg} \mathrm{bw}, \mathrm{P} 2$ given dexamethasone $0.13 \mathrm{mg} / \mathrm{kg}$ bw and vitamin $\mathrm{E}$ at a dose of $150 \mathrm{mg} / \mathrm{kg}$ bw, P3 given dexamethasone $0.13 \mathrm{mg} / \mathrm{kg}$ bw and vitamin $\mathrm{E}$ at a dose of $200 \mathrm{mg} / \mathrm{kgbw}$. Treatment was given for 14 days, then the experimental animals necropsied. Brain tissue was taken and processed for making histopathology preparations using hematoxylin-eosin staining. Variables examined include perivascular edema lesions and congestion. The result found a significant difference between negative and positive control. The mean score improvement of brain damage was not significantly different between the treatment P1, P2, and P3. P1 treatment groups showed mean score approached the negative control. The conclusions of this research was the dexamethasone caused histopathological changes to rat brains. Supplementation of vitamin E up to doses of $200 \mathrm{mg} / \mathrm{kg}$ of body weight have not been able to reduce the side effects of dexamethasone on the brain.
\end{abstract}

Keywords: brain; brains; damage; dexamethasone; vitamine $\mathrm{E}$ 


\section{PENDAHULUAN}

Saat ini kortikosteroid telah digunakan decara luas. Kortikosteroid juga dianggap sebagai obat "dewa" karena banyak penyakit dapat diobati dengan obat kortikosteroid, seperti anafilaktik, serangan asma yang berat, dan beberapa penyakit lainya. Salah satu jenis kortikosteroid sintetik adalah deksameason (Indranarum, 2003). Deksametason merupakan salah satu kortikosteroid sintetik yang mempunyai potensi baik. Kemampuannya dalam menaggulangi peradangan dan alergi, kurang lebih sepuluh kali lebih hebat dari pada yang dimiliki prednisone (Dharma, 2014). Deksametason mempunyai potensi anti inflamasi yang sangat kuat. Karena harganya yang murah dan mudah didapat, mengakibatkan deksametason masih menjadi obat andalan untuk terapi inflamasi (Samsuri et al., 2011). Efek samping penggunaan deksametason tersebar luas di beberapa organ. Ranta $e t$ al. (2006), melaporkan bahwa pemberian deksametason pada tikus menyebabkan kerusakan yang serius pada beberapa organ misalnya pada pankreas (Dharma, 2014), hati (Insani, 2014), ginjal (Ridho, 2010), dan lambung (Kusumaadhi, 2010). Vitamin E merupakan vitamin yang larut dalam lemak dan memiliki fungsi antioksidan yang tinggi (Brigelius-Flohe dan Traber, 1999). Antioksidan sangat penting dalam memerangi radikal bebas yang menyebabkan kerusakan sel. Antioksidan adalah senyawa yang dapat mencegah proses oksidasi yang disebabkan oleh radikal bebas, berupa efek samping pemberian deksametason. Vitamin merupakan senyawa organik yang diperlukan tubuh dalam jumlah kecil untuk mempertahankan kesehatan dan seringkali bekerja sebagai kofaktor untuk enzim metabolisme (Margail, 2005; Bebas et al, 2016).

Pada saat ini belum ada informasi mengenai pengaruh pemberian deksametason yang dikombinasikan dengan vitamin $\mathrm{E}$ terhadap sel otak.
Sebagaimana diketahui, otak dianggap sebagai organ yang mendapatkan distribusi obat fase pertama setelah penyerapan terjadi. Otak juga memiliki kemampuan untuk metabolisme obat dari beberapa jalur pemberian obat seperti injeksi secara subkutan (Renwick dan George, 1989; Ilett et al., 1990; Krishna dan Klotz, 1994; Suparman et al., 2013). Dari asumsi diatas, maka penelitian ini bertujuan untuk mengetaui pengaruh pemberian deksametason dan vitamin E terhadap sel otak.

\section{METODE PENELITIAN}

\section{Sampel Penelitian}

Sampel yang digunakan dalam penelitian ini adalah 25 ekor tikus putih (Rattus norvegicus) jantan berumur $2-3$ bulan, berat badan 200 - 300 gram yang didapatkan di kota Denpasar, Provinsi Bali.

\section{Prosedur Penelitian}

Tikus dibagi ke dalam lima kelompok yang terdiri dari: kelompok kontrol negatif $\mathrm{K}(-)$ yang hanya diberikan pakan dan minum saja. Kelompok kontrol positif $\mathrm{K}(+)$ yang diberikan deksametason secara injeksi subkutan dengan dosis $0,13 \mathrm{mg} / \mathrm{kg}$ berat badan. Kelompok (P1) yang diberikan deksametason secara injeksi subkutan dengan dosis $0,13 \mathrm{mg} / \mathrm{kg}$ berat badan dan vitamin $\mathrm{E}$ peroral dengan dosis $100 \mathrm{mg} / \mathrm{kg}$ berat badan. Kelompok (P2) yang diberikan deksametason secara injeksi subkutan dengan dosis $0,13 \mathrm{mg} / \mathrm{kg}$ berat badan dan vitamin $\mathrm{E}$ peroral dengan dosis $150 \mathrm{mg} / \mathrm{kg}$ berat badan. Kelompok (P3) yang diberikan deksametason secara injeksi subkutan dengan dosis $0,13 \mathrm{mg} / \mathrm{kg}$ berat badan dan vitamin $\mathrm{E}$ peroral dengan dosis $200 \mathrm{mg} / \mathrm{kg}$ berat badan. Perlakuan ini dilaksanakan selama dua minggu. Selanjutnya dilakukan nekropsi pada tikus kemudian diambil organ otak untuk pembuatan preparat histopatologi jaringan otak.

\section{Pembuatan Preparat}

Lima kelompok tikus yang telah diberi perlakuan selama dua minggu diambil 
organ otaknya untuk selanjutnya dilakukan pembuatan preparat dengan menggunakan metode pewarnaan Hematoxylin-Eosin (HE). Sampel organ otak yang diambil setelah dinekropsi dipotong dengan ukuran $1 \times 1 \times 1 \mathrm{~cm}$, kemudian direndam dengan larutan neutral bufer formalin (NBF). Kemudian sampel organ yang telah dipotong diperkecil lagi dengan irisan tipis untuk disimpan dalam tisue cassette dan difiksasi ke dalam larutan NBF. Setelah selesai fiksasi, kemudian dilakukan proses dehidrasi dan clearing dengan satu sesi larutan yang terdiri dari : alkohol $70 \%$, alkohol $80 \%$, alkohol $90 \%$, alkohol $96 \%$, alkohol absolut, toluene, dan parafin secara bertahap dalam waktu satu hari. Sampel organ diblocking dengan menggunakan embedding set yang dituangi parafin cair kemudian didinginkan. Blok yang sudah dingin disectioning menggunakan microtome dengan ketebalan \pm 4-5 mikron (Kiernan, 1990). Proses yang terakhir adalah pewarnaan dengan metode Harris Hematoxylin-Eosin (HE) dan mounting media. Selanjutnya preparat histopatologi diamati di bawah mikroskop dan dicatat perubahan mikroskopik yang ditemukan.

Variabel yang diperiksa dalam penelitian ini adalah Lesi kongesti dan lesi edema perivaskuler pada jaringan otak. Pemeriksaan mikroskopik dilakukan masing-masing pada 5 lapang pandang mikroskopik dengan pembesaran 400x. Hasil pemeriksaan selanjutnya diberi skor yaitu kongesti pada otak: 0 (jika tidak ada kongesti), 1 (jika ada kongesti bersifat fokal atau ringan), 2 (jika ada kongesti bersifat multifokal atau sedang), 3 (jika ada kongesti bersifat difusa atau berat). Lesi edema pada otak: 0 (jika tidak ada edema), 1 (jika ada edema bersifat fokal atau ringan), 2 (jika ada edema bersifat multi fokal atau sedang), dan 3 ( jika ada edema bersifat difusa atau berat).

\section{Analisis Data}

Data hasil pemeriksaan ditabulasi dan selanjutnya dianalisis dengan uji statistik non parametrik Kruskal-Wallis. Untuk mengetahui perbedaan antar kelompok dilanjutkan dengan uji Mann-Whitney (Steel dan Torrie, 1991)

\section{HASIL DAN PEMBAHASAN}

\section{Hasil}

Hasil pengamatan histopatologi otak tikus putih (Rattus norvegicus) berdasarkan lesi kongesti dan lesi edema. Pada semua kelompok perlakuan tersaji pada Tabel 1.

Tabel 1. Tabulasi hasil pemeriksaan histopatologi Otak tikus putih kategori kongesti dan edema pada semua kelompok perlakuan.

\begin{tabular}{lcccccccccc}
\hline \multicolumn{1}{c}{ Kkelompok } & \multicolumn{3}{c}{ Skor Kongesti } & \multicolumn{1}{c}{ Skor Edema } \\
\cline { 2 - 10 } & 0 & 1 & 2 & 3 & 4 & 0 & 1 & 2 & 3 & 4 \\
\hline Kontrol negatif K(-) & - & 5 & - & - & - & - & 4 & 1 & - & - \\
Kontrol positif K(+) & - & 2 & 3 & - & - & - & 1 & - & 4 & - \\
Vitamin E 100mg/kg (P1) & 1 & - & 4 & - & - & - & 2 & 3 & - & - \\
Vitamin E 150mg/kg (P2) & - & 2 & 3 & - & - & - & 2 & 3 & - & - \\
Vitamin E 200mg/kg (P3) & - & - & 4 & 1 & - & - & - & 4 & 1 & - \\
\hline
\end{tabular}

Keterangan. Skor 0: tidak terjadi perubahan, Skor 1 perubahan bersifat fokal, Skor 2: perubahan bersifat multifokal, Skor 3 : perubahan bersifat difusa

\section{Pembahasan}

Dari hasil uji Kruskal-Wallis menunjukkan perolehan nilai setiap perlakuan untuk edema adalah 0,033 . Nilai ini menunjukkan ada perbedaan nyata $(\mathrm{P}<0,05)$ antara kontrol negatif dengan kelompok perlakuan lain. Nilai setiap perlakuan untuk kongesti adalah 0,036 , ini berarti terdapat perbedaan nyata $(\mathrm{P}<0,05)$ antara kelompok kontrol negatif dengan kelompok perlakuan. Kategori edema dan kongesti terdapat perbedaan yang nyata 
$(\mathrm{P}<0,05)$ antara kelompok kontrol dengan kelompok perlakuan, maka dilanjutkan dengan uji Mann-Whitney untuk mengetahui perbedaan pengaruh antar dosis vitamin $\mathrm{E}$ yang diberikan.

Hasil dari uji Mann-Whitney untuk kategori edema adalah antara kelompok kontrol negatif dengan kontrol positif dan P3 terdapat perbedaan yang nyata $(\mathrm{P}<0,05)$, antara kontrol negatif dengan $\mathrm{P} 1$ dan P2 tidak terdapat perbedaan nyata $(\mathrm{P}>0,05)$. Kemudian antara kontrol positif dengan P1, P2, dan P3 tidak terdapat perbedaan yang nyata $(\mathrm{P}>0,05)$. Sedangkan P1 dengan P2 dan P3 tidak terdapat perbedaan nyata $(\mathrm{P}>0,05)$ dan $\mathrm{P} 2$ dengan $\mathrm{P} 3$ juga tidak terdapat perbedaan yang nyata $(\mathrm{P}>0,05)$.

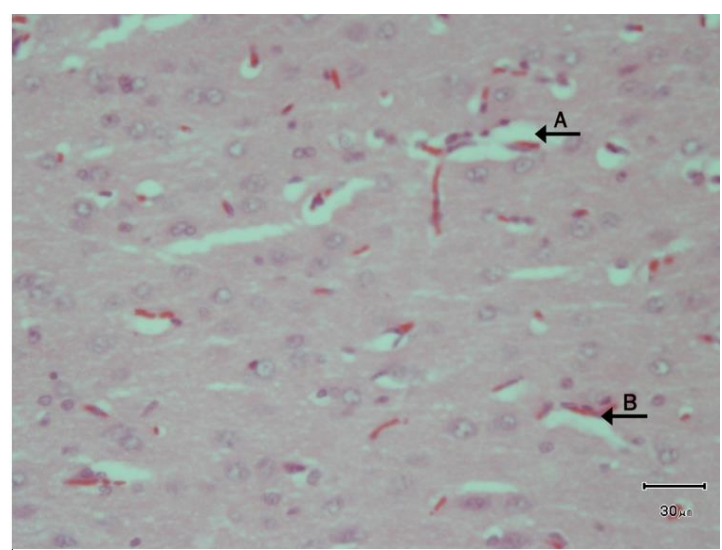

Gambar 1. Gambaran histopatologi otak tikus putih (Rattus norvegicus) pada kelompok kontrol negatif,( HE, 400X ). Terlihat adanya edema(A), dan kongesti (B).

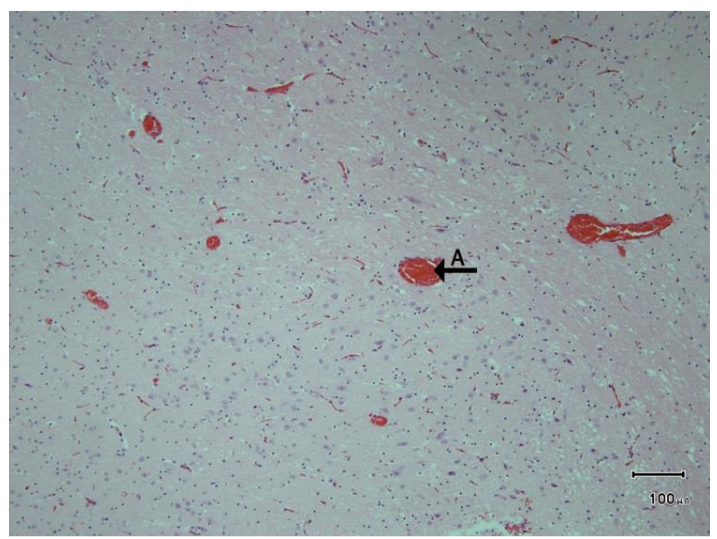

Gambar 2. Gambaran histopatologi otak tikus putih (Rattus norvegicus) pada kelompok kontrol Positif, ( HE,200X ). Terlihat adanya kongesti (A).

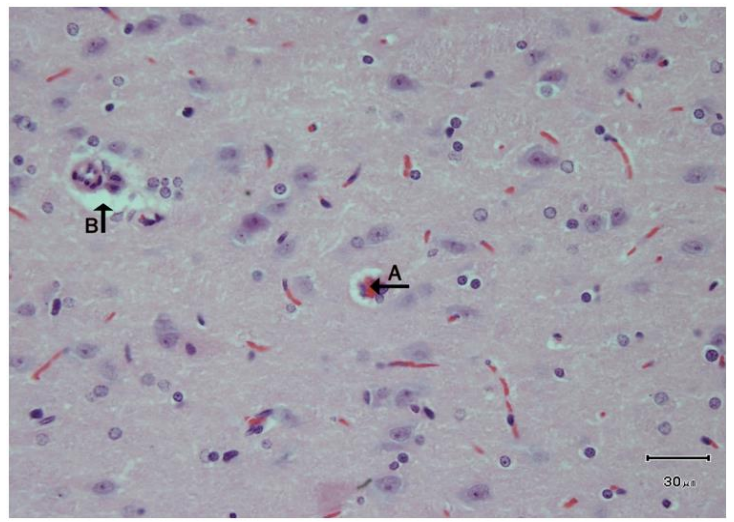

Gambar 3. Gambaran histopatologi otak tikus putih (Rattus norvegicus) pada kelompok kontrol P1, ( HE, 400X). Terlihat adanya kongesti (A) dan edema (B).

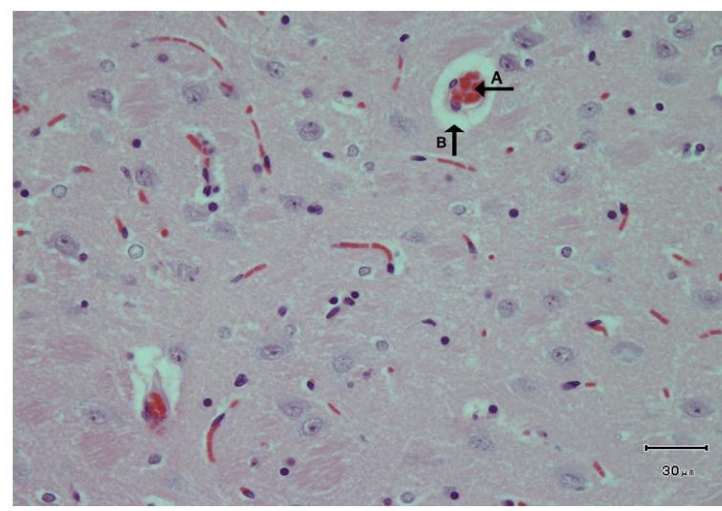

Gambar 4. Gambaran histopatologi otak tikus putih (Rattus norvegicus) pada kelompok kontrol P2, ( HE, 400X). Terlihat adanya kongesti (A) dan edema (B).



Gambar 5. Gambaran histopatologi otak tikus putih (Rattus norvegicus) pada kelompok kontrol P3, ( HE. 400X) Terlihat adanya kongesti (A) bersifat multifokal dan edema (B) 
Hasil penelitian ini menunjukkan bahwa pemberian deksametason menyebabkan perubahan histopatologi otak tikus putih (Rattus norvegicus) dilihat dari lesi kongesti dan edema perivaskuler. Pemberian suplemen vitamin E terhadap efek samping deksametason $(0,13 \mathrm{mg} / \mathrm{kg})$ pada otak tikus putih pada kategori kongesti maupun edema belum mampu memperbaiki kerusakan jaringan otak akibat pemberian deksametason. Dilihat dari hasil pada perlakuan kontrol positif yang diberi deksametason $(0,13 \mathrm{mg} / \mathrm{kg})$ menunjukkan kerusakan ditandai dengan terjadinya kongesti dan edema yang bersifat sedang atau multifokal akibat dari efek radikal bebas dari deksametason yang berikatan dengan sel otak. Pengamatan pada morfologi organ otak secara mikroskopis pada semua kelompok memperlihatkan bahwa batas lapisanlapisan cortex cerebri tidak jelas. Hal ini menunjukkan bahwa perubahan yang terjadi pada batas antar lapisan cortex cerebri bukan karena pengaruh perlakuan. Gambaran lain pada kontrol negatif yang ditemukan adalah edema dan kongesti ringan sampai sedang pada pembuluh darah cortex cerebri yang juga terlihat pada semua kelompok. Hal ini dapat dipahami bahwa perubahan yang terjadi pada pembuluh darah cortex cerebri mungkin karena cedera dislokasi otak tikus putih. Cedera hipoksia lebih mempengaruhi korteks serebral dari pada batang otak (Baron, 2006).

Perubahan di sekitar jaringan yang dapat diamati adalah adanya edema vasogenik pada kelompok perlakuan serta ditemukan pada kontrol negatif meskipun bersifat ringan dan juga ditemukan pada kontrol positif yang bersifat sedang atau multifokal. Edema ini terjadi akibat cairan secara pasif terkumpul di ruang interstitial setelah pecahnya sawar darah otak, yang disebabkan oleh meningkatnya tekanan hidrostatik misalnya akibat sumbatan aliran darah vena (Fadilah et al., 2015). Sebagai mana diketahui, oedema vasogenik juga sering menyertai kasus stroke yang juga menyebabkan iskhemia (Rick, 2003).

Pada penelitian ini didapatkan hasil suplementasi vitamin dapat menyebabkan perbaikan meskipun secara statistik tidak signifikan $(\mathrm{P}>0,05)$, khususnya pada dosis vitamin $100 \mathrm{mg} / \mathrm{kg}$. Pada dosis vitamin $\mathrm{E}$ $150 \mathrm{mg} / \mathrm{kg}$ dan $200 \mathrm{mg} / \mathrm{kg}$ belum terlihat mengalami perbaikan. Pemberian vitamin E secara oral selama 2 minggu pada tikus putih (Rattus norvegicus) yang sudah diberi deksametason belum terbukti mampu memperbaiki kerusakan sel otak yang sebelumnya diberikan deksametason pada semua perlakuan. Hal ini mungkin dikarenakan pada kelompok P1 dosis vitamin E $100 \mathrm{mg} / \mathrm{kg}$ dan dosis vitamin $\mathrm{E}$ $150 \mathrm{mg} / \mathrm{kg}$, merupakan dibawah dosis yang menghambat stres oksidatif yaitu 200 $\mathrm{mg} / \mathrm{kg}$ (Tome et al., 2010). Sehingga pemberian vitamin $\mathrm{E}$ dosis $100 \mathrm{mg} / \mathrm{kg}$ dan $150 \mathrm{mg} / \mathrm{kg}$ tidak mampu menghambat kerusakan sel otak yang terjadi. Hal ini menggambarkan bahwa vitamin $\mathrm{E}$ berperan membantu fungsi sistem sitokrom oksidase atau untuk melindungi susunan lipida di dalam mitokondria dari kerusakan oksidasi yang diakibatkan oleh radikal bebas (Brigelius-Flohe dan Traber, 1999).

\section{Simpulan:}

\section{SIMPULAN DAN SARAN}

Pemberian deksametason menyebabkan perubahan histopatologi otak tikus putih. Pemberian suplementasi vitamin E sampai dosis $200 \mathrm{mg} / \mathrm{kg}$ tidak mampu mengurangi efek deksametason pada otak.

\section{Saran}

Perlu Penelitian yang lebih lanjut tentang pemberian suplementasi vitamin $\mathrm{E}$ dengan dosis lebih dari $200 \mathrm{mg} / \mathrm{kg}$ untuk mendapatkan efek perbaikan jaringan otak akibat efek samping dari pemberian deksametason dosis $0,13 \mathrm{mg} / \mathrm{kg}$.

\section{UCAPAN TERIMA KASIH}

Ucapan terima kasih kepada staff Balai Besar Veteriner Denpasar, Laboratorium 
Patologi dan Farmakologi Veteriner FKH Universitas Udayana yang telah membantu selama penelitian ini berlangsung.

\section{DAFTAR PUSTAKA}

Baron MD. 2006. Neuroanestesia and Intensive Care. Brief Review: History, Concept And Controversies In The Neurological Determination Of Death. Can. J. Anesth. 53(6): 602-608.

Bebas W, Geovany LB, Budiasa MK. 2016. Penambahan Vitamin E Pada Pengencer BTS Terhadap Daya Hidup Dan Motilitas Spermatozoa Babi Landrace Pada Penyimpanan $15^{\circ} \mathrm{C}$. Bul. Vet. Udayana. 8(1): 1-7.

Brigelius-Flohe R, Traber MG. 1999. Vitamin E: Function and Metabolism. Maryland. FASEB. J. 13.

Dharma IGBS. 2014. Pengaruh Pemberian Suplementasi Vitamin E Terhadap Efek Samping Deksametason pada Pankreas Tikus Putih (Skripsi). Fakultas Kedokteran Hewan. Universitas Udayana.

Fadilah MF, Berata IK, Kardena M. 2015. Studi Histopatologi Limpa Anjing Penderita Distemper Dikaitkan Dengan Sebaran Sel-Sel Radang Pada Otak Dan Paru. Bul. Vet. Udayana. 7(2): 194-201.

Ilett KF, Tee LBG, Reeves PT and Minchin RF. 1990. Metabolism of drugs and other xenobiotics in the gut lumen wall. Pharmacol. Ther. 46: 6793.

Indranarum T, Marowardoyo S. 2003. Kadar plasma kortisol pada beberapa macam manifestasi efek samping kortikosteroid pada kulit. J. Berkala Ilmu Penyakit Kulit dan Kelamin. 15.

Insani A. 2014. Pengaruh Pemberian Suplementasi Vitamin E Terhadap Efek Samping Deksametason pada Hati Tikus Putih (Skripsi). Fakultas Kedokteran Hewan. Universitas Udayana.

Krishna DR dan Klotz U. 1994. Extrahepatic metabolism of drugs in humans. Clin. Pharmacokinet. 26: 144-160.

Kusumaadhi ZM. 2010. Artikel karya ilmiah : Pengaruh Pemberian Deksametason Dosis Bertingkat Per Oral 30 Hari Terhadap Kerusakan Mukosa Lambung Tikus Wistar. Fakultas Kedokteran. Universitas Diponegoro.

Margaill I. 2005. Antioxidant strategies in the treatment of stroke. Free. Rad. Biol. Med. 39(4): 429-443.

Ranta F, Avram D, Berchtolf S, Dufer M, Drews G, Lang F, dan Ullrich S. 2006. Original Article : Dexamethasone Induces Cell Death in InsulinSecreting Cells, an Effect Reversed by Exendin-4. USA. American Diabetes Association.

Renwick AG, and George CF. 1989. Metabolism of xenobiotics in the gastrointestinal tract, in Intermediary Xenobiotic Metabolism in Animals: Methodology, Mechanisms and Significance. (Huston DH, Caldwell J and Paulson GD eds) pp 13-40, Taylor \& Francis, London

Rick MD. 2003. Correlation between Brain Reorganization, Ischemic Damage and Neurologic status after Transient Focal Cerebral Ischemia in Rats; A Functional Magnetic Resenance Imaging study. J. Neurosci. 23(8): 510-517.

Ridho MR. 2010. Artikel karya ilmiah : Pengaruh Pemberian Deksametason Dosis Bertingkat Per Oral 30 Hari Terhadap Kerusakan Tubulus Ginjal Tikus Wistar. Fakultas Kedokteran. Universitas Diponegoro.

Samsuri, Rahardjo, Sudjarwo. 2011 . The influences of Dexamethasone sodium phosphate to Insulin and Glucose level in young male rats body (Rattus norvegicus). Asosiasi Farmakologi dan Farmasi Veteriner Indonesia.

Stell RGD, dan Torrie JH. 1991. Principles and Procedures of Statistic. A Biomedical Approach. Second Edition. Tokyo: Mc. Grow Hill. 
Suparman P, Sudira W, Berata IK. 2013. Kajian Ekstrak Daun Kedondong (Spondias dulcis G.Forst.) Diberikan Secara Oral Pada Tikus Putih Ditinjau Dari Histopatologi Ginjal. Bul. Vet. Udayana. 5(1): 49-56.
Tome ME, Lutz NW, Briehl MM. 2004. Overexpression of catalase or Bcl-2 alters glucose and energy metabolism concomitant with dexamethasone resistance. Biochim. Biophys. Acta. 1693: $57-72$. 